\title{
琵琶湖集水域からの污溞物流出特性に関するシミュレーション解析
}

\section{SIMULATIONS OF POLLUTANT RUNOFF FROM LAKE BIWA BASIN}

\author{
市木敦之* 大西敏之** 山田淳* \\ Atsushi ICHIKI *, Toshiyuki OHNISHI ** and Kiyoshi YAMADA *
}

\begin{abstract}
The objectives of this study are to simulate pollutant runoff load into Lake Biwa using Macro Model and examine the runoff characteristics of pollutants. As a result of the simulations, runoff pollutant load in every river which flowed into Lake Biwa was calculated. And the runoff characteristics of pollutants during dry weather days and storm events from Lake Biwa basin were examined in consideration of the characteristics of the basin. In the results, some available knowledge concerned with the environmental management in Lake Biwa basin was obtained.
\end{abstract}

KEYWORDS ; characteristics of a river basin, environmental management in a basin, Lake Biwa, Macro Model, pollutant runoff

\section{1.はじめに}

近畿圈1400万人の水源である琵琶湖は、集水面 積が広大でかつ大小 100 以上の流入河川を有して いる。こうした集水域から流入した污濁物は、長 い滞留時間を通じて直接的に、あるいは湖内の底 質成分となって間接的に、琵琶湖水質に影響を及 ぼしている。そのため、琵琶湖の水質保全を議論 するためには、巨視的にではあっても、集水域か らの污濁物流出量や流出特性を把握しておく必要 がある。琵琶湖流入河川を対象とした污濁物流出 調査は、これまで多く行われており、國松ら ${ }^{1)}$ 主に山林や農地を流下する河川において自然系負 荷を対象とした流出調査を実施しており、また筆 者ら ${ }^{2)}$ 市街化区域を流域内に有する河川におい て市街地ノンポイント負荷を対象とした同様の流 出調查を継続的に行ってきた。しかし、いずれも 調查で対象とした個々の流域における事例評価と しての検討は行われているものの、得られた成果 を援用して琵琶湖集水域全域からの流出特性が検

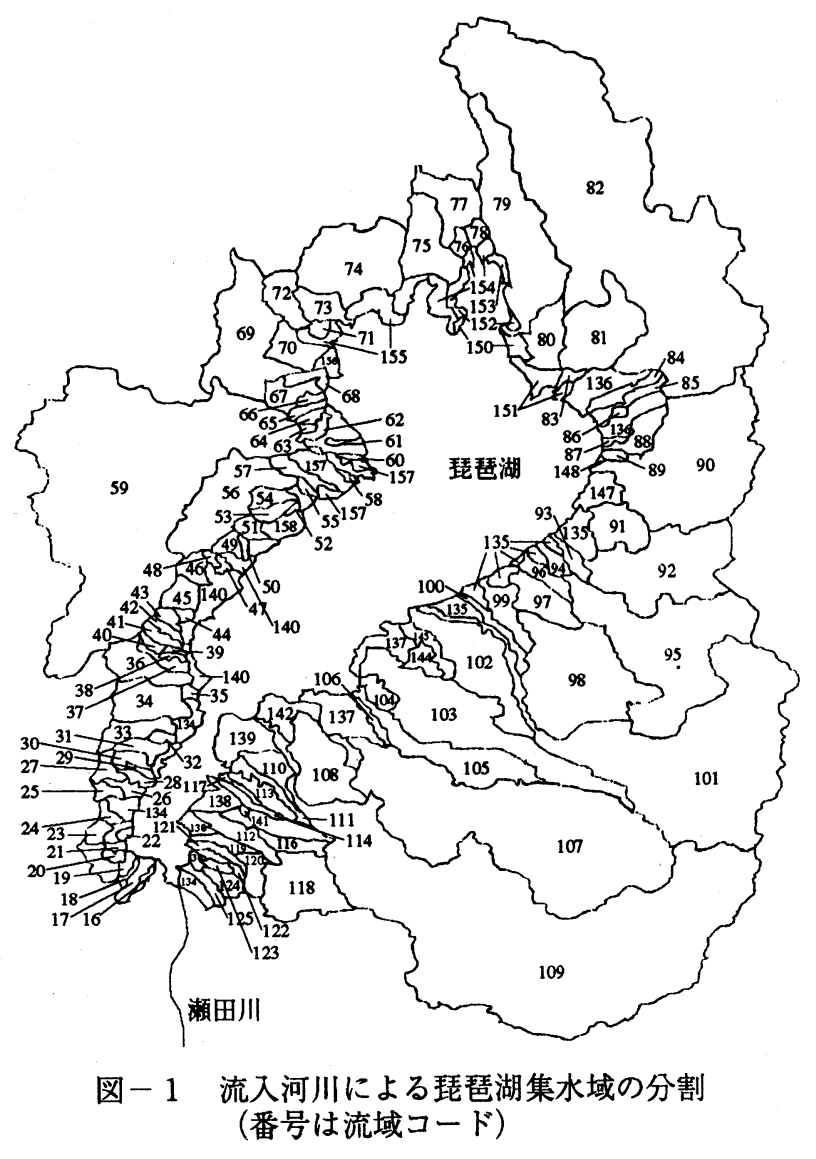


討された例 $^{32-5)}$ (少ない。近年、琵琶湖への流出負荷量に関する将来予測の試み ${ }^{6)}$ や琵琶湖水質改善を目 指した実験施設の検討 ${ }^{7)}$ が行われつつあるものの、それらが依拠すべき現在の集水域における污濁物流出特 性についての情報に乏しいのが現状である。従来、集水域からの流出負荷量の推定計算には、原単位法が用 いられることが多かった ${ }^{8)}$ が、こした手法では、流域構造の違いや降雨をはじめとする水文因子によって ダイナミックに変化する污濁物の流出特性を的確に表現できないため、筆者らは流域特性や晴・雨天時別の 流出特性を考慮した污濁物流出モデル

（以下「マクロモデル」とする）を提 案し、污濁物流出のシミュレーション 解析を実施してきた $\left.{ }^{92} \cdot 10\right)$ 。本研究 は、非常に巨視的にではあっても琵琶 湖集水域全域からの污濁物流出特性を 議論するためのフレームワークを作る ことを目的とし、ここでは、マクロモ デルを琵琶湖集水域に適用し、流入河 川毎に栄養塩に関する流出シミュレー ションを行うことにより、琵琶湖への 污濁物流出特性について定量的な検討 を試みた。

\section{2.琵琶湖集水域の概要}

琵琶湖からの唯一の流出河川である 瀬田川へ直接流入する河川流域を除い た琵琶湖集水域を、流入河川流域によ り区分して図ー 1 に、また1990年現在 の各流入河川流域の概要を表 -1 に示 す。琵琶湖集水域には、雨水流出成分 が河川を経由せずに、小水路等によっ て直接琵琶湖へ流出している流域（一 級河川流域外）が含まれるため、ここ では、当該流域 (流域コード134〜159) を、その所在する市町村名で表記し、 併せて琵琶湖流入河川流域としてい る。各流入河川流域のフレーム值 を、琵琶湖集水域についてまとめたも のが表ー2である。ただし、ここでは

\begin{tabular}{|c|c|c|c|c|c|c|c|c|c|c|c|}
\hline $\begin{array}{l}\text { 流城 } \\
\Xi-1\end{array}$ & 泀川名 & 区分 & 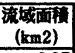 & \begin{tabular}{|c|} 
流域人口 \\
(u) \\
\end{tabular} & \begin{tabular}{|l|} 
下水道 \\
及茟(\%) \\
\end{tabular} & \begin{tabular}{|l|} 
流域 \\
$\Xi-1$
\end{tabular} & 河川名 & 区分 & \begin{tabular}{|c|}
$\begin{array}{c}\text { 流域面保 } \\
(\mathrm{km} 2)\end{array}$ \\
\end{tabular} & \begin{tabular}{c|} 
流域人口 \\
$(\mathrm{U})$
\end{tabular} & $\begin{array}{l}\text { 下水道兽 } \\
\text { 及隼 }(\%) \\
\end{array}$ \\
\hline 16 & 突田川 & 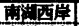 & 0.87 & \begin{tabular}{|r|}
4916 \\
\end{tabular} & 100.0 & \begin{tabular}{|l|}
83 \\
\end{tabular} & IFind & 北江了离 & \begin{tabular}{|l|}
10.36 \\
\end{tabular} & \begin{tabular}{|r|}
1324 \\
\end{tabular} & \begin{tabular}{|l|}
25.1 \\
\end{tabular} \\
\hline 17 & का & 葓 & 0.89 & 2711 & 98.3 & 84 & 米川 & 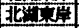 & 2.43 & 13168 & 0.4 \\
\hline 18 & 相而II & 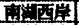 & 3.10 & 4724 & 100.0 & 85 & $t-11$ & 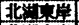 & 1.92 & 9199 & 0.4 \\
\hline 19 & क世U & 雮造西㟶 & 0.61 & 5307 & 100.0 & 86 & 而夏川 & 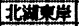 & 0.95 & 3053 & 0.4 \\
\hline 20 & 吾形同 & H浩票展 & 1.87 & 2050 & 100.0 & 87 & (1) & 西: & 1.05 & 359 & 0.3 \\
\hline 21 & 百々川 & 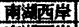 & 1.26 & 5276 & 100.0 & 88 & \pm III & 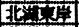 & 8.42 & 3536 & 0.3 \\
\hline 22 & 不页川 & 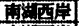 & 1.16 & 1326 & 100.0 & 89 & चकたा & 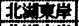 & 6.12 & 1765 & 0.0 \\
\hline 23 & mII & 苚法西学 & 2.73 & 3982 & 39.2 & 90 & 天扠 & 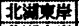 & 86.86 & 27724 & 0.5 \\
\hline 24 & 芬川 & 雨酒致 & 3.05 & 4260 & 22.3 & 91 & 知川 & 北江了 & 14.58 & 3994 & 0.0 \\
\hline 25 & 四ッ谷川 & 雨纤西离 & 2.93 & 2175 & 24.2 & 92 & Fा川 & $z^{2}+1 \sqrt{1}$ & 27.41 & 10473 & 0.0 \\
\hline 26 & 万机 & 南端学 & 1.63 & 1331 & 24.2 & 93 & 乎田11 & 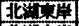 & 1.50 & 16576 & 0.0 \\
\hline 27 & 大宫川 & 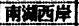 & 6.13 & 3361 & 35.6 & 94 & की.JII & 北江岸 & 1.21 & 12534 & 0.0 \\
\hline 28 & 是饬川 & 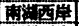 & 1.11 & 2401 & 100.0 & 95 & 犬上川 & 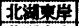 & 35.79 & 14136 & 0.7 \\
\hline 29 & (1) & 南海要常 & 1.06 & 4639 & 100.0 & 96 & 江面川 & 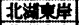 & 1.71 & 5785 & 0.0 \\
\hline 30 & 大正寺川 & 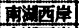 & 2.99 & 1663 & 38.4 & 98 & 字시 & 北凉 & 315.33 & 49442 & 10.1 \\
\hline 31 & tisil & 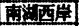 & 5.12 & 2419 & 22.1 & 99 & 文趼 & 北江可 & 6.90 & 9215 & 0.0 \\
\hline 32 & 倍骂而 & 南站: 西愿 & 1.53 & 958 & 46.5 & 100 & 不㙂川 & 北江笋 & 13.34 & 5258 & 0.0 \\
\hline 33 & 天神川 & 苚站西崖 & 9.83 & 4226 & 40.2 & 101 & 知川 & 北次唩 & 218.43 & 14182 & 14.6 \\
\hline 34 & C (3) & 霜膘社 & 20.53 & 6377 & 22.4 & 102 & 大同川 & 北江塧 & 166.07 & 35515 & 3.0 \\
\hline 35 & 丹出川 & 北西覃 & 1.38 & 6136 & 95.1 & 103 & 長苓寺川 & 北: h下 & 208.15 & 58052 & 7.7 \\
\hline 36 & 和问) & 北涪㶾常 & 17.67 & 2534 & 0.3 & 104 & 八iIII & 北㗊 & 5.48 & 10468 & 17.9 \\
\hline 37 & IUग & 北漂学 & 4.42 & 1051 & 0.0 & 105 & 香馬川 & 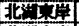 & 30.56 & 21997 & 11.5 \\
\hline 38 & 㪇寺川 & 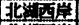 & 2.37 & 96 & 0.0 & 106 & 大邦川 & 北古崔 & 1.27 & 3556 & 0.0 \\
\hline 39 & 生川 & 北江西原 & 1.03 & 91 & 0.0 & 107 & 旦矛似 & 北市展 & 183.39 & 59468 & 6.0 \\
\hline 40 & 天㸪 & 北西覃 & 2.37 & 443 & 0.0 & 108 & 䒠住川 & 北本傽 & 45.57 & 30949 & 41.9 \\
\hline 41 & NH户 & 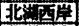 & 3.16 & 415 & 0.0 & 109 & 5满川II & $\mathrm{E}^{2} \mathrm{I}, \mathrm{J}$ & 217.02 & 111327 & 8.3 \\
\hline 42 & Q7. 911 & $E^{2} \leq \sqrt{-14}$ & 1.20 & 437 & 0.0 & 110 & 法奠川 & 青: 1 & 8.49 & 10411 & 23.2 \\
\hline 43 & 䢶川 & 北洒宸 & 0.95 & 362 & 0.0 & 111 & 天神川 & 薄紧 & 2.70 & 5684 & 32.3 \\
\hline 44 & 大III & 菲溧事 & 1.39 & 182 & 0.0 & 112 & 守山111 & 薄流 & 5.32 & 10140 & 45.0 \\
\hline 45 & 大谷川 & 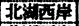 & 3.41 & 729 & 0.0 & 113 & 山र川 & 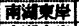 & 3.97 & 10949 & 62.1 \\
\hline 46 & 比良川 & 北来西常 & 2.64 & 319 & 0.0 & 114 & 场川 & 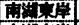 & 2.47 & 2302 & 0.1 \\
\hline 47 & 実谅 & 北洒西事 & 0.99 & 297 & 0.0 & 116 & (4)川 & 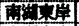 & 22.86 & 33257 & 27.8 \\
\hline 48 & 大听 & 北酒票 & 0.63 & 120 & 0.0 & 117 & 佐々川 & 䱜江崖 & 15.55 & 34133 & 54.3 \\
\hline 49 & 流 & 北涀严 & 1.87 & 480 & 0.0 & 118 & 章漌川 & 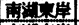 & 34.43 & 7736 & 28.4 \\
\hline 50 & 北11 & 北涪曋覃 & 0.49 & 116 & 0.0 & 119 & 山寺川 & 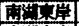 & 5.31 & 9996 & 47.4 \\
\hline 51 & III & 北涪西篃 & 5.49 & 216 & 8.3 & 120 & 伯母川 & 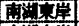 & 14.79 & 13612 & 22.6 \\
\hline 52 & D川 & 北江西票 & 0.67 & 263 & 17.9 & 121 & 北川 & 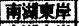 & 2.90 & 2622 & 12.9 \\
\hline 53 & 小田川 & $\mathrm{U}^{\prime}$ & 4.56 & 634 & 17.8 & 122 & 韵川 & 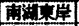 & 2.82 & 4566 & 64.8 \\
\hline 54 & 和田内川 & 北酒嵒 & 6.79 & 784 & 17.9 & 123 & +旃寺川 & 南沺揫 & 3.60 & 2796 & 26.3 \\
\hline 55 & HII & 北洒覃 & 0.91 & 475 & 17.7 & 124 & 楾川 & 南江学 & 12.01 & 10466 & 13.1 \\
\hline 56 & 2गII & 北栖票 & 52.60 & 2978 & 13.8 & 125 & 長沢任 & 南况新 & 3.08 & 8261 & 88.4 \\
\hline 57 & 五川 & 北西学 & 4.53 & 2568 & 0.6 & 134 & 大海宋 & 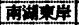 & 25.65 & 98258 & 70.8 \\
\hline 58 & 金丸川II & 北栖㟶 & 0.56 & 590 & 0.0 & 135 & 振苗 & 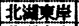 & 9.45 & 26543 & 0.0 \\
\hline 59 & काओ & 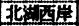 & 202.07 & 7222 & 0.2 & 136 & 長浜市 & 批政 & 11.10 & 26072 & 0.4 \\
\hline 60 & 輬川 & 北西变 & 1.83 & 732 & 1.4 & 137 & 近工八市 & 北江重 & 31.71 & 12477 & 9.1 \\
\hline 61 & 䍏川 & 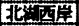 & 1.70 & 714 & 1.4 & 138 & 章章市 & 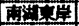 & 31.64 & 17361 & 16.5 \\
\hline 62 & 㽖井川 & 酒覃 & 14.35 & 1557 & 1.4 & 139 & 守山市 & 霜江程 & 21.29 & 20028 & 18.8 \\
\hline 63 & 林照寺川 & 北酒复 & 8.42 & 141 & 1.4 & 140 & 志西 & 北畆覃 & 39.11 & 5611 & 1. \\
\hline 64 & 今川 & 北洒离 & 12.49 & 196 & 1.5 & 141 & 耊地了 & 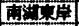 & 1.62 & 1622 & 46.5 \\
\hline 65 & 波布谷川 & 北酒崖 & 7.19 & 130 & 1.5 & 142 & 中主丁 & 北江常 & 20.48 & 3522 & 7.2 \\
\hline 66 & 庄䔬川 & 北栖部 & 1.92 & 923 & 1.4 & 143 & 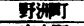 & 北江常 & 5.86 & 2108 & 0.0 \\
\hline 67 & 天्गाI & 北洒尊 & 31.10 & 1675 & 1.4 & 144 & 安土初 & 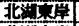 & 14.16 & 1397 & 0. \\
\hline 68 & 今清川 & 北和䙵新 & 3.73 & 2139 & 1.4 & 145 & 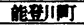 & 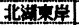 & 22.03 & 1541 & 1.8 \\
\hline 69 & 石田II & 北洒党 & 87.62 & 2974 & 1.4 & 146 & 知川 I & 北洪坚岸 & 0.67 & 3 & 0. \\
\hline 70 & 场 & 北菏亚 & 12.63 & 2105 & 1.4 & 147 & 粨通 & 北江页牢 & 3.15 & 5108 & 0. \\
\hline 71 & 斬保川 & 北涪西崖 & 1.85 & 441 & 10.0 & 148 & 近江U & 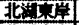 & 1.61 & 469 & 0.0 \\
\hline 72 & 百何 & 北江西崖 & 16.26 & 958 & 5.2 & 149 & 成搰了 & 北江了 & 0.67 & 167 & 0.0 \\
\hline 73 & 生来川 & 北泣西竹 & 8.20 & 1194 & 10.0 & 150 & 满打 & 北涪高 & 4.56 & 1375 & 24.1 \\
\hline 74 & 知内川 & 北洒严 & 57.93 & 2117 & 10.0 & 151 & एका & 北江常 & 47.89 & 6232 & 30.8 \\
\hline 75 & 太洏川 & 北的西㸺 & 25.82 & 1701 & 9.5 & 152 & 高胢 & 北江了 & 4.27 & 160 & 4.4 \\
\hline 76 & 岩请川 & 菲涪西覃 & 3.26 & 282 & 9.6 & 153 & 木之元 I & 北次事 & 0.15 & 389 & 0. \\
\hline 77 & 大JII & 北涪西原 & 18.61 & 1357 & 9.5 & 154 & 西娍井宁 & 北涪 & 12.16 & 1500 & 9.5 \\
\hline 78 & 大理川 & 北酒崖 & 3.18 & 502 & 9.6 & 155 & マキ而 & 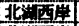 & 11.33 & 2338 & 10.0 \\
\hline 79 & 余賗川 & 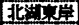 & 43.96 & 11852 & 8.4 & 156 & 今洴丁 & 北湮㬓 & 3.65 & 3058 & 1.4 \\
\hline 80 & 丁II杊 & 北累崖 & 44.93 & 6303 & 20.1 & 157 & 安仪 & 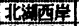 & 7.73 & 7292 & 0.0 \\
\hline 81 & 町I & 菲洼崖 & 67.76 & 14967 & 5.6 & 158 & DIJ & 北漂崖 & 11.19 & 1963 & 17.8 \\
\hline 82 & 峬川 & 北渵東岸 & 152.92 & 24140 & 3.2 & 159 & 新的 & 北浾西崖 & 17.20 & 5039 & 1.4 \\
\hline
\end{tabular}
北湖, 南湖にそれぞれ流入する河川を東岸 㑡，西岸側に区分することにより、琵琶湖流 入河川を 4 カテゴリー（北湖東岸, 北湖西 岸, 南湖東岸, 南湖西岸) にグルーピングし ている (北湖流入河川は大川 (流域コード77) と大坪川（流域コード78）の間を、南湖流 入河川は瀬田川（琵琶湖集水域外）を境に

表 -2 琵琶湖集水域の概要（1990年現在）

\begin{tabular}{|c|c|c|c|c|c|c|c|c|c|}
\hline \multirow{2}{*}{ 区 } & \multirow{2}{*}{ 分 } & \multirow{2}{*}{$\begin{array}{c}\text { 流入 } \\
\text { 河川数 }\end{array}$} & \multirow{2}{*}{$\begin{array}{l}\text { 集水 } \\
\text { 面積 } \\
\left(\mathrm{km}^{2}\right)\end{array}$} & \multicolumn{4}{|c|}{ 土地利用 (\%) } & \multirow{2}{*}{$\begin{array}{c}\text { 流域 } \\
\text { 人口 } \\
\text { (X干人) }\end{array}$} & \multirow{2}{*}{$\begin{array}{c}\text { 下水道 } \\
\text { 普及率 } \\
(\%)\end{array}$} \\
\hline & & & & 市街地 & 田 & 畑 & 山林 & & \\
\hline \multirow{2}{*}{$\begin{array}{l}\text { 北 } \\
\text { 湖 }\end{array}$} & 東岸 & 46 & 2111 & 5.47 & 18.21 & 2.35 & 73.97 & 679.4 & 7.6 \\
\hline & 西岸 & 50 & 732 & 2.87 & 12.41 & 1.49 & 83.23 & 76.7 & 11.0 \\
\hline \multirow{2}{*}{$\begin{array}{l}\text { 南 } \\
\text { 湖 }\end{array}$} & 東岸 & 19 & 221 & 21.00 & 39.11 & 4.56 & 35.34 & 304.2 & 47.0 \\
\hline & 西岸 & 19 & 68 & 11.93 & 15.38 & 0.34 & 72.35 & 64.1 & 66.5 \\
\hline \multicolumn{2}{|c|}{ 全 域 } & 134 & 3132 & 6.10 & 18.26 & 2.26 & 73.38 & 1124.4 & 21.8 \\
\hline
\end{tabular}


東西に区分）。集水面積が大きく、かつ大部分の 河川が流入している北湖と比較して、南湖では、 流域に占める市街地の比率や下水道普及率が相対 的に高いのが特徴的である。

3. マクロモテルを用いた污濁物流出シミュレー ション

\section{1 マクロモテルの概要}

マクロモデルは、污濁物の流出挙動が発生源や 晴雨により大きく異なることを考慮して構筑され ており、その構成およびパラメータの同定に関し ては、すでに既報 ${ }^{9)}{ }^{1}{ }^{10)}$ で示されている。前述の ように、本研究ではシミュレーションにより流出 負荷量を琵琶湖集水域全域において議論するため のフレームワークを示すことが目的であるが、シ ミュレーションモデルについて精度の評価が十分 でないと、幾分かの誤差を包含しつつも得られた シミュレーション結果自体が一人歩きしかねな い。そのため、ここでは、流域内に市街地・非市 街地とも一定面積を占める伊佐々川（流域 コード117）において、筆者らが1994年 11 月1日から 1 年間継続的に行った污濁物流 出の実態調査 ${ }^{11)}$ を基に、本モデルの再現 性を検討した。調查では、降雨量, 流量の 測定を行うとともに、流量に降雨時流出の 影響が現れ始めた時点から降雨終了後、平 時の流量に戻るまでの間の直接流出量を降 雨時流出量と考え、流量比例でコンポジッ トした採水試料の水質を分析した。また、

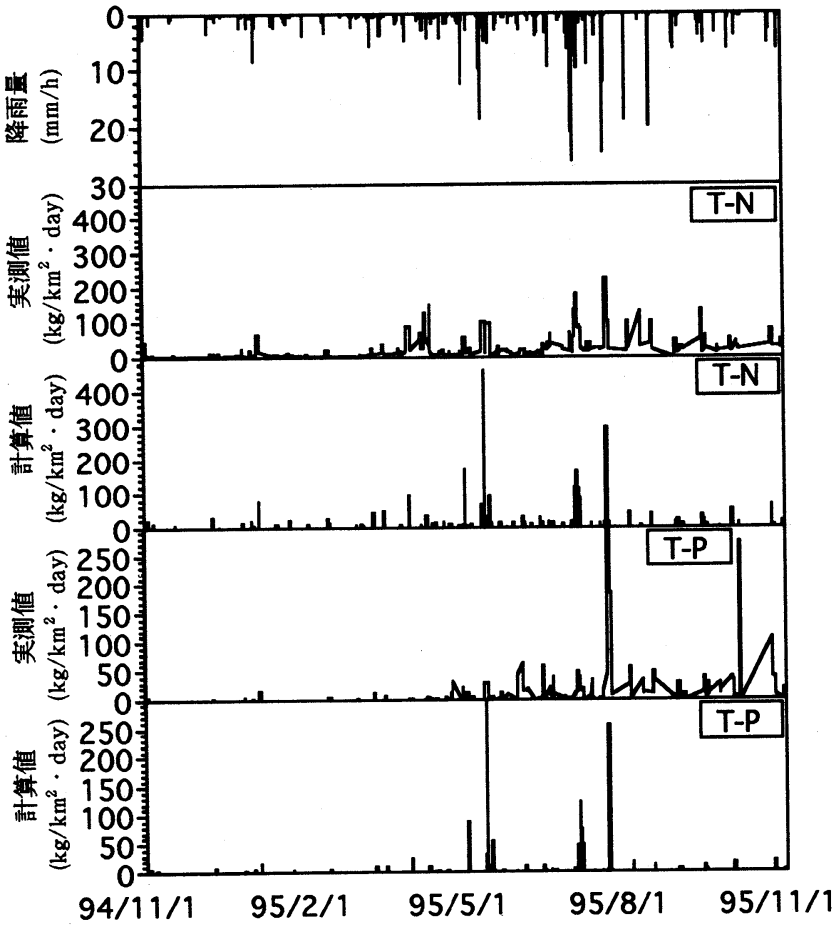

図-2 比流出負荷量の実測值と計算値の比較（伊佐々川） 同時にバックグラウンド值として降雨前後の平水時試料の水質 分析も行った。調査を継続した 1 年間の降水量は、 1449.5 $\mathrm{mm} / \mathrm{y}$ となったが、これはこの地域でのほぼ平均的な年降水量 と考えてよい。調查の結果とシミュレーションによる計算值を 経時変動図にして図ー 2 に示す。シミュレーションの計算時間 ステップは 1 日であるため、継続時間が数日に及ぶ大きな降雨 のあった梅雨期や秋雨期における計算値が、一降雨平均負荷量 を示す実測值に比べて大きい場合が見受けられるものの、おお よその変動についての再現性は確認できる。実測値と計算値の 関係をみるため、両者について、流出時間を考慮した月別の積 算比流出負荷量を算定して、相関図にしたものが図ー3であ る。T-N, T-P とも概ね実测值と計算值は一致している。特に T-Nでは、降雨の集中する梅雨期や秋雨期における流出負荷量

表一3 入力（降水量時系列）データの概要

\begin{tabular}{|c|c|c|}
\hline \multicolumn{2}{|c|}{ 期間 } & $1980 / 1 / 1-1990 / 1 / 1$ \\
\hline \multicolumn{2}{|c|}{ 日数 (d) } & 3654 \\
\hline \multicolumn{2}{|c|}{ 総降水量 (mm) } & 15623.3 \\
\hline \multirow{3}{*}{$\begin{array}{c}\text { 年降水量 } \\
(\mathrm{mm} / \mathrm{y})\end{array}$} & 最大 & $\begin{array}{c}2042.0 \\
\text { (1980年) }\end{array}$ \\
\hline & 平均 & 1562.3 \\
\hline & 最小 & $\begin{array}{c}1161.0 \\
(1984 \text { 年) }\end{array}$ \\
\hline \multirow{6}{*}{$\begin{array}{c}\text { 降水量区分 } \\
\text { と } \\
\text { 日数の分布 } \\
\text { (d) }\end{array}$} & $0 \sim 0.5 \mathrm{~mm}$ & 2424 \\
\hline & $0.5 \sim 10 \mathrm{~mm}$ & 752 \\
\hline & $10 \sim 30 \mathrm{~mm}$ & 331 \\
\hline & $30 \sim 100 \mathrm{~mm}$ & 137 \\
\hline & $100 \sim \mathrm{mm}$ & 10 \\
\hline & 合計 & 3654 \\
\hline
\end{tabular}


を過小に評価する傾向があるものの、他の期間においては実測值と計算值の差がほとんどない。既報 ${ }^{10)}$ に おける流域毎の再現精度の検討結果と総合して、個別の流域に関して精緻な流出特性の議論を行うにはまだ 相当の課題があるものの、本研究で意図する巨視的な傾向の検討には十分な精度とみなし、以下シミュレー ション解析を試みた。

\section{2 シミュレーションの方法と結果}

シミュレーションでは、各流入河川流域について、表ー 1 に示したそれぞれ固有の流域フレーム值（1990 年現在）を用い、過去 10 年間に京都地方気象台で観測された降水量の時系列データ（平均年降水量 1562.3 $\mathrm{mm} / \mathrm{y})$ をマクロモデルに入力することにより、日単位の栄養塩流出負荷量を算定し、結果を平均して污濁 物の年間流出挙動を再現した。ただし、ここでは大気降下物, 畜産排水, 地下水流出成分に加えて、下水処 理水による流出負荷量を検討の対 象外としている。そのため、特に ポイント負荷については、あくま で陸域からの流出段階の負荷量の みが対象となっている。表－3に 入力した降水量時系列データの概 要を示す。本来、特に北湖への流 出負荷量を議論する際には、融雪 期の污濁物流出挙動や降水量の地 域分布を考虑すべきであるが、融 雪期の流出を表す簡易なモデルが ないことや巨視的な枠組みを作る という観点から、ここでは、融雪 にともなう污濁物の流出は、降雨 時流出と同じものとして、前述し た方法によってシミュレーション を行った。シミュレーション結果 を各流域における年間比流出負荷 量についてまとめたものを、表一 4 に示す。

\section{4. 琵琶湖集水域における污濁物 流出特性}

\section{1 污漓物流出量の流域間比较}

シミュレーション結果を各河川 の年平均流出負荷量について降順 にまとめたものを、表一 5 に示 す。T-N, T-Pとも集水面積が大 きい河川ほど流出負荷量が大き く、上位20河川からの合計流出負 荷量が総流出負荷量の $50 \%$ 以上を 占めていることから、琵琶湖への

\begin{tabular}{|c|c|c|c|c|}
\hline $\begin{array}{l}\text { 流枝 } \\
z-k\end{array}$ & 河川名 & 区公 & 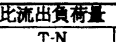 & $\frac{(\operatorname{ton} / \mathrm{km} 2 \cdot \mathrm{y})}{\mathrm{T} \cdot \mathrm{P}}$ \\
\hline 16 & 兵田川 & 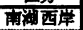 & 1.09 & 0.93 \\
\hline 17 & 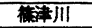 & 雨神西席 & 1.83 & 1.01 \\
\hline 18 & 相相开 & 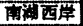 & 2.53 & 2.07 \\
\hline 19 & 需世川 & 雨的西席 & 1.20 & 0.63 \\
\hline 20 & 吾责川 & 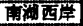 & 2.49 & 1.44 \\
\hline 21 & 百名川 & 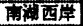 & 2.07 & 1.18 \\
\hline 22 & 不制的 & 雨䋨西席 & 2.29 & 1.32 \\
\hline 23 & 砇川 & 南湖西学 & 3.17 & 0.50 \\
\hline 24 & 新 & 南榊西学 & 4.26 & 0.56 \\
\hline 25 & 四ッ谷川 & 南維西章 & 3.94 & 0.45 \\
\hline 26 & 仍机 & 南济西岸 & 3.74 & 0.48 \\
\hline 27 & 大富川 & 雨河西度 & 3.78 & 0.54 \\
\hline 28 & 是洗川 & 斗榊西部 & 2.28 & 2.27 \\
\hline 29 & 高稆川 & 南科西犝 & 2.96 & 4.21 \\
\hline 30 & 大正寺川 & 雨鸿西学 & 4.18 & 0.80 \\
\hline 31 & 姩理川 & 角神西章 & 5.47 & 0.77 \\
\hline 32 & 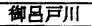 & 雨䙍西辛 & 3.92 & 1.05 \\
\hline 33 & 天神川 & 南湖西常 & 4.31 & 1.27 \\
\hline 34 & 真湟川 & 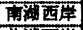 & 5.39 & 0.79 \\
\hline 35 & 舟川 & 北㨽西展 & 2.80 & 6.05 \\
\hline 36 & 和需形 & 北湖西席 & 4.64 & 0.29 \\
\hline 37 & 害㩲川 & 北湖西岸 & 11.00 & 0.59 \\
\hline 38 & 真光寺川 & 北被西席 & 14.32 & 0.85 \\
\hline 39 & 生川 & 北榊西岸 & 12.17 & 0.71 \\
\hline 40 & 天川 & 北湖西学 & 10.56 & 0.62 \\
\hline 41 & 八量戸川 & 北湖西厈 & 9.75 & 0.49 \\
\hline 42 & 動栍子小 & 北湖西席 & 8.13 & 0.24 \\
\hline 43 & 木所川 & 北湖西覃 & 4.61 & 0.25 \\
\hline 44 & 大ाI & 北榊西学 & 8.23 & 0.45 \\
\hline 45 & 大谷川 & 北湖西席 & 4.52 & 0.21 \\
\hline 46 & 比良川 & 北湖西岸 & 4.55 & 0.20 \\
\hline 47 & 家校川II & 北湖西厈 & 4.63 & 0.22 \\
\hline 48 & 天堂川 & 北湖西度 & 6.97 & 0.37 \\
\hline 49 & 滝而 & 北初西席 & 5.13 & 0.27 \\
\hline 50 & 北川 & 北湖西席 & 3.78 & 0.21 \\
\hline 51 & inI & 北湖西房 & 4.45 & 0.22 \\
\hline 52 & Fiा & 北湖西章 & 4.20 & 0.32 \\
\hline 53 & 小画川 & 北湴西学 & 4.62 & 0.30 \\
\hline 54 & 和畐丙川I & 北被西度 & 6.29 & 0.42 \\
\hline 55 & 鲉川 & 北海西童 & 10.24 & 1.04 \\
\hline 56 & 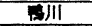 & 北湖西学 & 4.97 & 0.29 \\
\hline 57 & 高井川 & 北榊西席 & 8.88 & 0.47 \\
\hline 58 & 金丸川 & 北湖西度 & 18.05 & 0.95 \\
\hline 59 & 安形 & 北榊西席 & 0.89 & 0.04 \\
\hline 60 & 神奈川 & 北湖西席 & 11.21 & 0.60 \\
\hline 61 & 南川 & 北河西童 & 12.82 & 0.71 \\
\hline 62 & 田弄川 & 北激西章 & 6.01 & 0.23 \\
\hline 63 & 林照寺川 & 北海西席 & 4.90 & 0.19 \\
\hline 64 & डाI & 北视西席 & 5.07 & 0.21 \\
\hline 65 & 波布谷川 & 北湖西学 & 4.73 & 0.19 \\
\hline 66 & 生界川 & 北测西度 & 4.92 & 0.27 \\
\hline 67 & 天川I & 菲湖西度 & 4.62 & 0.19 \\
\hline 68 & 今津川 & 北湖西章 & 6.15 & 0.36 \\
\hline 69 & 石畐川 & 北被西章 & 2.36 & 0.10 \\
\hline 70 & 境川 & 北浽西席 & 6.31 & 0.28 \\
\hline 71 & 新保川 & 北溜西学 & 5.97 & 0.37 \\
\hline 72 & 百流川 & 北酒西岸 & 4.47 & 0.20 \\
\hline 73 & 生来川 & 北湖西席 & 5.40 & 0.29 \\
\hline 74 & 知丙川1 & 北湖西席 & 2.38 & 0.12 \\
\hline 75 & 大溥川 & 北酒西章 & 6.70 & 0.36 \\
\hline 76 & 岩粤川 & 北湂西席 & 6.00 & 0.55 \\
\hline 77 & 大川I & 北湖西席 & 5.80 & 0.30 \\
\hline 78 & 大趼川 & 北湖西岸 & 7.13 & 0.41 \\
\hline 79 & 余具川 & 北湖束障 & 4.12 & 0.29 \\
\hline 80 & 丁偅木川 & 北沙東章 & 5.52 & 0.43 \\
\hline 81 & 畍川 & 北湖東席 & 6.79 & 0.30 \\
\hline 82 & 㚴川 & 北湖東岸 & 1.87 & 0.08 \\
\hline
\end{tabular}

\section{シミュレーション結果)}

\begin{tabular}{|c|c|c|c|c|}
\hline 流牫 & & & 比流出页神量 & $(\operatorname{ton} / \mathrm{km} 2 \cdot \mathrm{y})$ \\
\hline$\Xi-F$ & 河川名 & 区分 & $\mathrm{T} \cdot \mathrm{N}$ & $\mathrm{T}-\mathrm{P}$ \\
\hline 83 & ल运而 & 北滥東常 & 5.62 & 0.53 \\
\hline 84 & 米川 & 北满来岸 & 17.20 & 1.66 \\
\hline 85 & $7-\pi$ & 北端柬岸 & 16.08 & 1.53 \\
\hline 86 & 萧酘量川 & 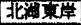 & 17.32 & 1.37 \\
\hline 87 & 深阿川 & 北滆来恧 & 10.89 & 0.39 \\
\hline 88 & \pm 土ाI & 北济東岸 & 7.81 & 0.41 \\
\hline 89 & びわだ川 & 北酒来岸 & 6.74 & 0.33 \\
\hline 90 & 天喕川 & 北湖東学 & 3.53 & 0.17 \\
\hline 91 & 知面川 & 北湖東岸 & 5.12 & 0.28 \\
\hline 92 & F川 & 北湖東首 & 3.48 & 0.21 \\
\hline 93 & 平畐川 & 北湖宩䎡 & 11.62 & 2.17 \\
\hline 94 & 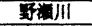 & 北洞東学 & 13.41 & 2.21 \\
\hline 95 & 犬上川 & 北湖菄岸 & 2.54 & 0.61 \\
\hline 96 & 江面川 & 北湖東章 & 12.44 & 1.27 \\
\hline 98 & 字簘的 & 北湖柬碚 & 2.67 & 0.16 \\
\hline 99 & 文机川 & 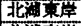 & 11.06 & 0.89 \\
\hline 100 & 不䇉川 & 北洲東学 & 4.84 & 0.28 \\
\hline 101 & 知川 & 北湖柬岸 & 1.02 & 0.06 \\
\hline 102 & 太同川 & 北湖柬岸 & 2.96 & 0.15 \\
\hline 103 & 長命寺川 & 北湖菄岸 & 5.08 & 0.34 \\
\hline 104 & $\Lambda \|$ & 北榊東岸 & 7.85 & 0.65 \\
\hline 105 & 白岛川 & 北洲東掌 & 4.60 & 0.43 \\
\hline 106 & 大舅川 & 北湖東岸 & 14.47 & 1.44 \\
\hline 107 & 百副川 & 北湖東牢 & 1.51 & 0.09 \\
\hline 108 & 家校川 & 北海東岸 & 5.33 & 1.47 \\
\hline 109 & 雷洲川 & 北湖東岸 & 1.06 & 0.09 \\
\hline 110 & 法竟川 & 南湖東岸 & 7.26 & 1.18 \\
\hline 111 & 天神川 & 南满東岸 & 6.65 & 1.63 \\
\hline 112 & 守山川 & 雨站東岸 & 6.08 & 2.49 \\
\hline 113 & 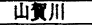 & 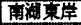 & 4.47 & 3.20 \\
\hline 114 & 境川 & 南涪東岸 & 12.04 & 0.97 \\
\hline 116 & 萧山川 & 南湖東度 & 4.63 & 1.14 \\
\hline 117 & 伊佐々川 & 雨港東岸 & 4.59 & 1.97 \\
\hline 118 & 莗涪川 & 雺湖東童 & 3.22 & 0.56 \\
\hline 119 & 山寺川 & 南㸚東席 & 4.88 & 1.65 \\
\hline 120 & 伯母川 & 雨部来辛 & 3.59 & 0.34 \\
\hline 121 & 北川 & 雨端策部 & 5.70 & 0.53 \\
\hline 122 & 前川 & 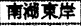 & 4.42 & 3.22 \\
\hline 123 & 干梅寺川 & 南初東覃 & 7.36 & 1.29 \\
\hline 124 & 狼川 & 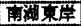 & 4.79 & 0.41 \\
\hline 125 & 長沢川 & 南榊果常 & 2.79 & 2.52 \\
\hline 134 & 大津市 & 南被柬俘 & 2.75 & 1.54 \\
\hline 135 & 旁根节 & 北榊東常 & 8.33 & 0.87 \\
\hline 136 & 長捠市 & 北湖東岸 & 14.88 & 1.04 \\
\hline 137 & 近江八雷 & 北湴東席 & 5.95 & 0.50 \\
\hline 138 & 莗津市 & 南湖東岸 & 8.62 & 1.02 \\
\hline 139 & 守山市 & 南榊来席 & 7.47 & 1.00 \\
\hline 140 & 志督酊 & 北湖西学 & 10.98 & 0.70 \\
\hline 141 & 巢菄軛 & 南被菓席 & 6.55 & 0.51 \\
\hline 142 & 中主町 & 北袖東学 & 8.42 & 0.46 \\
\hline 143 & 到洲町 & 北湖東岸 & 12.46 & 0.83 \\
\hline 144 & 安土阿 & 北满東席 & 7.95 & 0.26 \\
\hline 145 & 育至川町 & 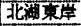 & 6.22 & 0.25 \\
\hline 146 & 夏知川的 & 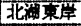 & 5.78 & 0.26 \\
\hline 147 & 米原町 & 北湖東岸 & 9.92 & 0.68 \\
\hline 148 & 近江叮 & 北湖東市 & 6.04 & 0.23 \\
\hline 149 & 虎姬町 & 北湖来晕 & 14.02 & 0.72 \\
\hline 150 & 蹒北軛 & 北湖東岸 & 8.88 & 0.86 \\
\hline 151 & びか町 & 北稒東新 & 4.76 & 0.49 \\
\hline 152 & 高月町 & 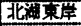 & 4.44 & 0.20 \\
\hline 153 & 木之元町 & 北湖東学 & 4.92 & 0.61 \\
\hline 154 & 西洨井町 & 北湖東更 & 5.12 & 0.25 \\
\hline 155 & マキ人町 & 北视西学 & 6.00 & 0.34 \\
\hline 156 & 今洪䁌 & 北泪西席 & 8.35 & 0.56 \\
\hline 157 & 要掼川町 & 北湖西学 & 10.90 & 0.59 \\
\hline 158 & 高島町 & 北酒西岸 & 6.35 & 0.42 \\
\hline 159 & 新起町 & 北湖西学 & 8.66 & 0.43 \\
\hline
\end{tabular}


流出負荷量は、こうした限られた幾つかの大河川にかなり依存していることがわかる。また、T-N 流出負荷 量では、降順に市街地面積の比率が大きくなるのにともなって、相対的に田畑，山林などの非市街地からの 流出分が隇少しているのに対して、T-P 流出負荷量とそれらの関係は明瞭ではない。表-6 6 は、各河川の年 平均流出負荷量を流域面積で除した比流出負荷量について降順に整理したものである。T-N 比流出負荷量と 市街地面積比率の間に一定の傾向が認められるのは、表－ 5 の場合とよく似た傾向であるが、ここでは、集 水面積が小さい都市河川が上位に位置している。この点については T-Pにおいても同様で、流域に占める市 街地の比率が大きい河川ほど上位に位置する結果となった。しかし、T-N の場合とは異なり、下水道普及率 にともなって T-P 比流出負荷量が増加傾向を示しており、市街地を発生源とするかなりの量のノンポイント 系負荷が、分流式雨水管をはじめとする排水系統を通じて流出しているものと推察される。

表 -5 流域からの年間流出負荷量（負荷量について降順）

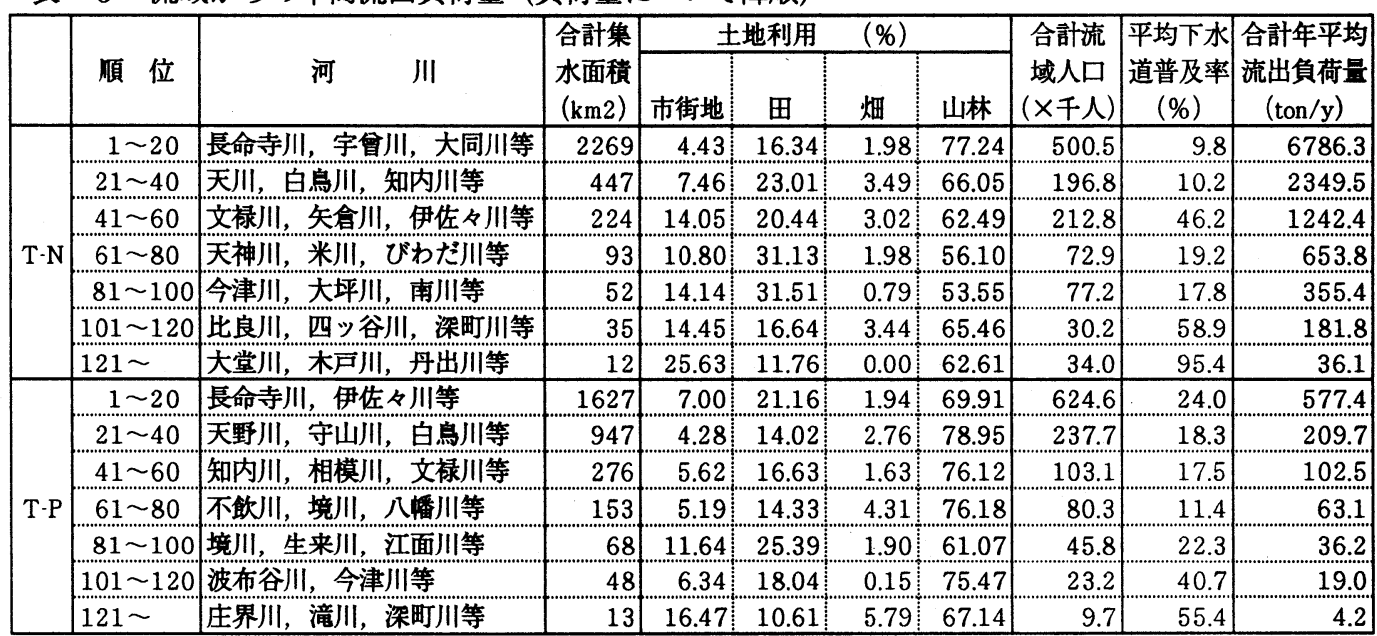

表-6 流域からの年間比流出負荷量（比負荷量について降順）

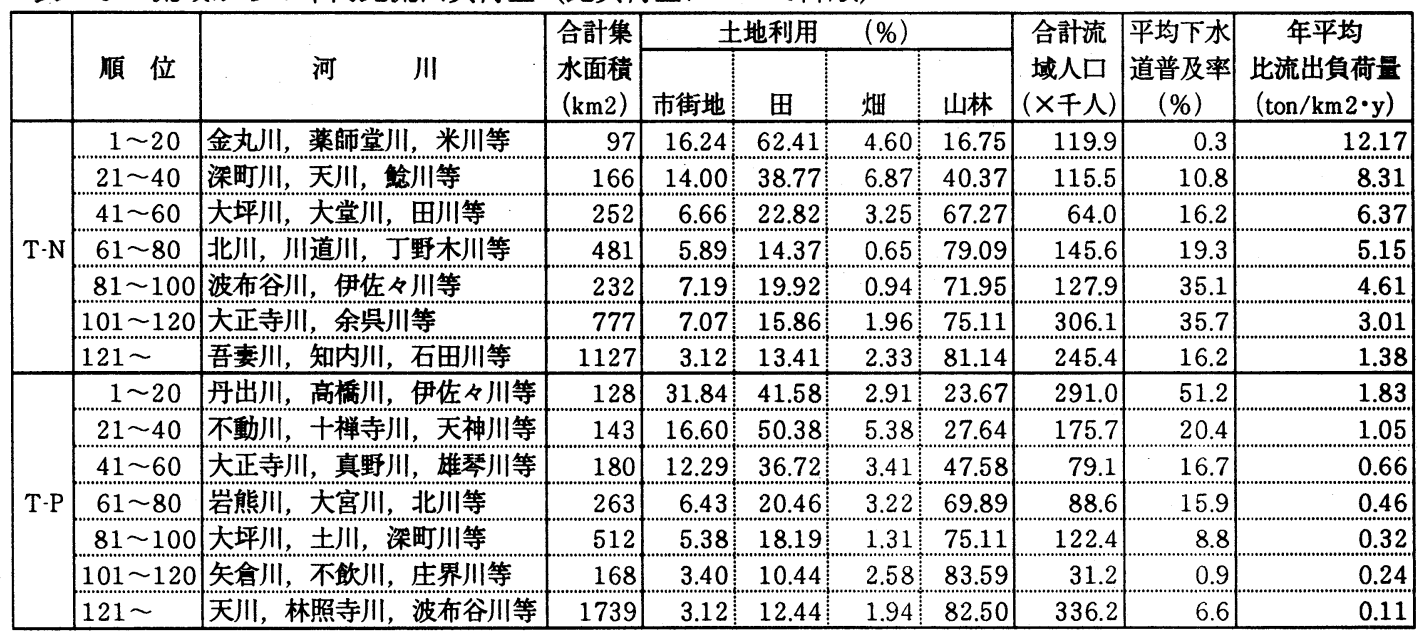

污濁物の流出挙動は晴天時と降雨時で大きく異なるため、シミュレーション結果を晴雨天時別の平均流出 負荷量について降順にまとめて、表-7に示す。晴天時流出負荷量については、一部で集水面積や人口・産 業密度，山林からの基底流出分などの影響により傾向が不明瞭なところもあるものの、 $\mathrm{T}-\mathrm{N} ・ \mathrm{~T}-\mathrm{P}$ を、下 水道整備によるドラスティックな流出負荷の削減勃果が認められる。一方、降雨時流出負荷量については、 こうした効果は顕著でなく、特に T-Pでは、下水道整備との関係が不明瞭になっている。表ー8 時別の比流出負荷量について降順に整理したものである。晴天時比流出負荷量については、T-Nでは下水道 
表-7 流域からの晴雨天時別流出負荷量（負荷量について降順）

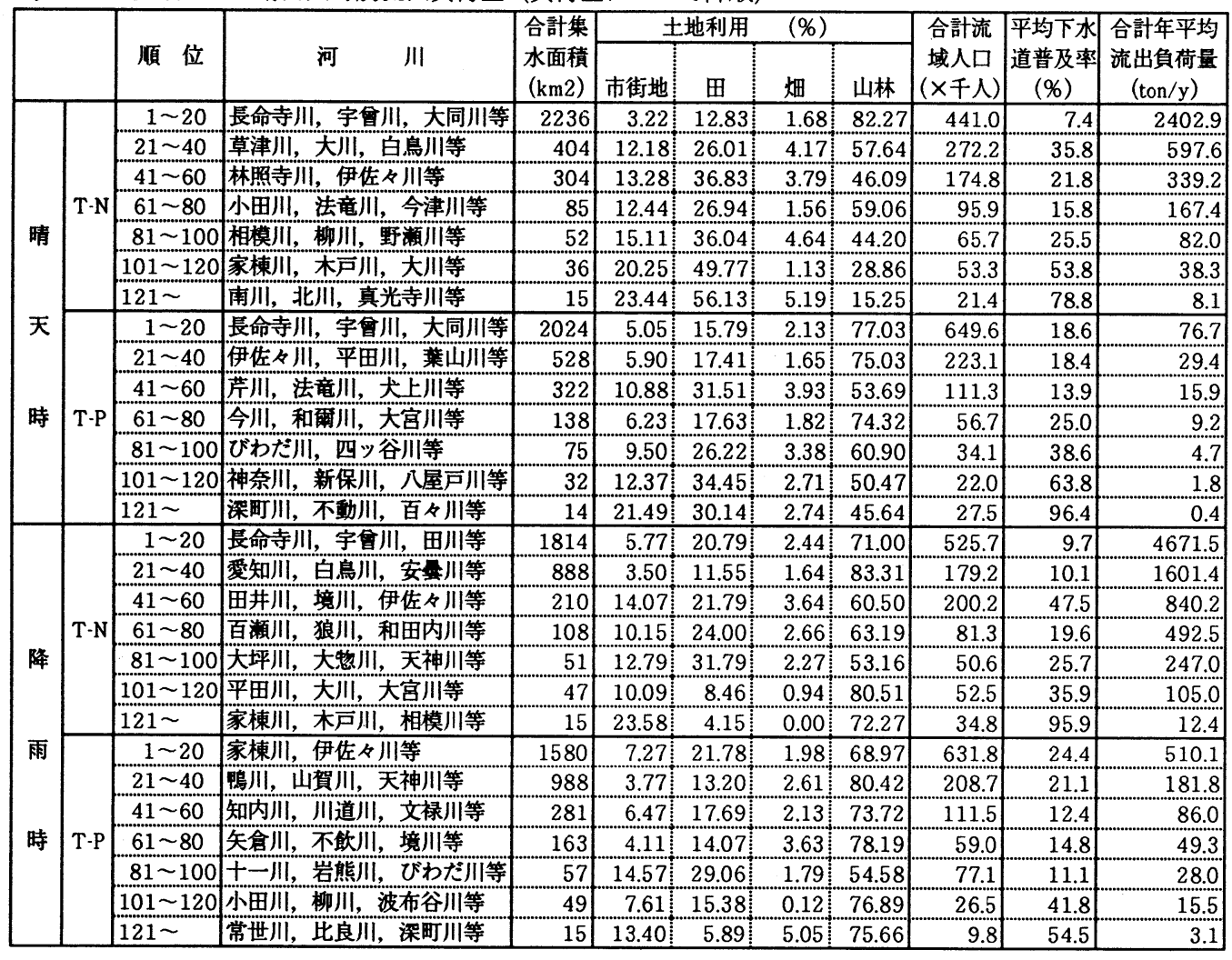

表-8 流域からの晴雨天時別比流出負荷量（比負荷量について降順）

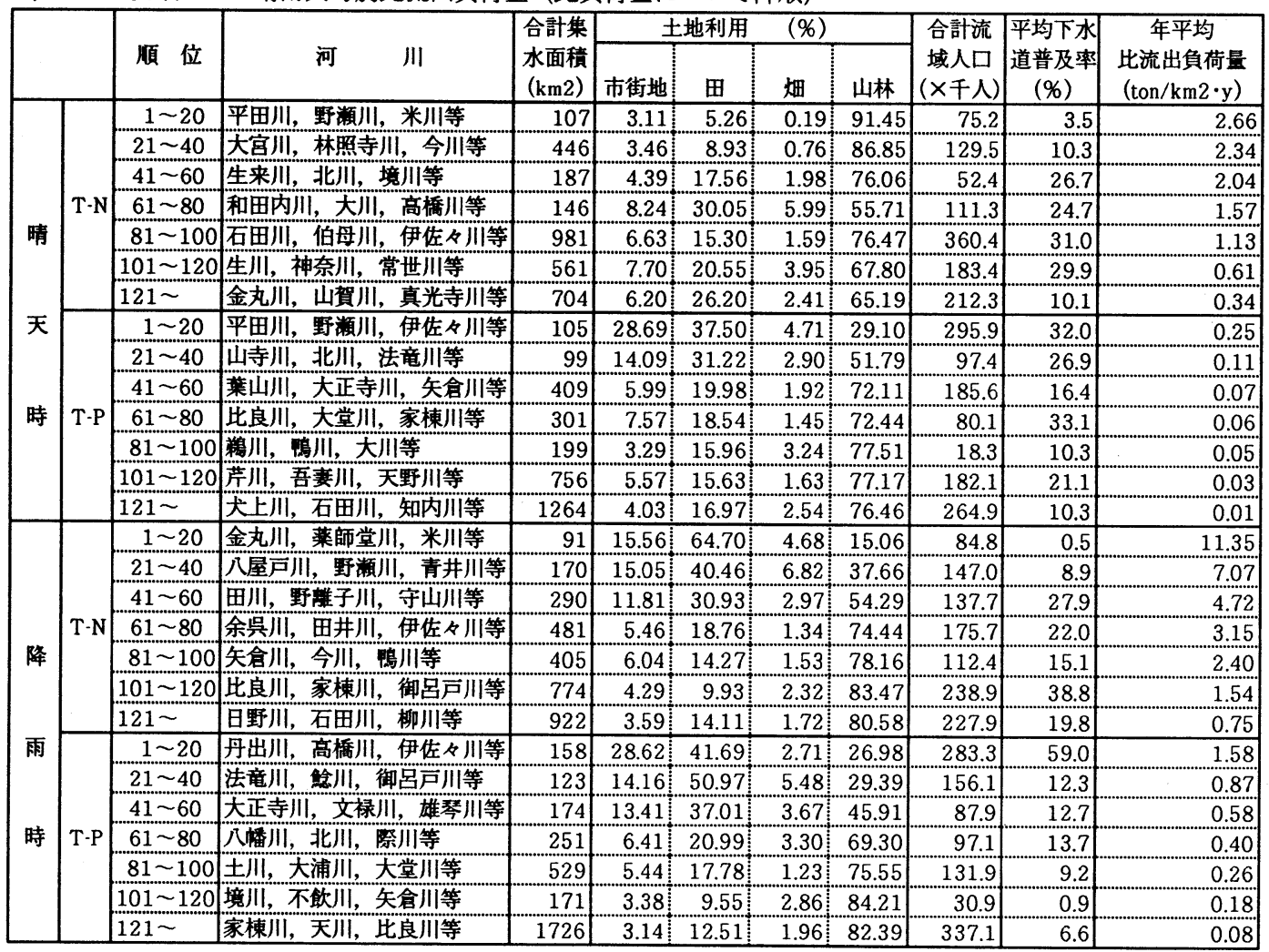


普及率の小さい山地河川, T-P では都市河川が、それぞれ上位に位置しており、污濁発生源が異なることに よる特性の違いが明瞭である。降雨時比流出負荷量については、表ー6で見られたのと同じ傾向が認められ、 年間流出特性がこうした降雨時流出によってかなり支配されていることが分かる。

\section{2 降雨時流出を考虙した污挶物流出特性の評価}

流域からの流出污濁負荷量は降水量によって大きく変動するため、各カテゴリーからの流出負荷量を降水 規模別にまとめて表 -9 に示した。 $30 \mathrm{~mm} / \mathrm{d}$ 以上の大きな降水は年間 15 日しかないものの、その間の比流出 負荷量は年間值の 39.6 7 $75.9 \%$ 占めており、污濁物流出の集中性が示されている。この傾向は、小さな降 雨でも一定の流出量があり比較的流出しやすいと考えられる T-Nよりも、T-Pで強く、また T-N 比流出負荷 量では各カテゴリ一間の差がほとんどないのに対して、T-Pでは南湖における比流出負荷量が北湖の $4 \sim 5$ 倍の大きさになっていることから、琵琶湖への T-P 流出量が時間的・地域的に著しく偏っていることがわか る。各降水量区分における平均日比流出負荷量 $\left(\mathrm{kg} / \mathrm{km}^{2} \cdot \mathrm{d}\right)$ については、カテゴリー毎に降水量によって、 T-Nで最大 90 318倍， T-Pで最大531〜 1603倍の差があり、污濁物流出の降水量依存性亡大降雨集中性が非 常に顕著であることが示されている。

图－4（1），（2）は、月別の T-N, T-P 比流出負荷量とその流出源比率を示したものである。T-Nで は、北湖における流出負荷量のほとんどが非市街地からの流出分であり、月降水量の大小に応じて、晴天時 自然系負荷 (非市街地) や降雨時ノンポイント負荷（非市街地）の比率が、月別比流出負荷量の中で大きな ウエイトを占めている。北湖に比べて、南湖では晴天時・降雨時のポイント負荷や降雨時ノンポイント負荷 （市街地）の比率が大きく、特に南湖東岸で は、降水量の少ない月には、晴天時ポイント 負荷が流出比負荷量の最大 $18.9 \%$ を占めるに 至っている。一方 T-Pでは、降雨が集中する 梅雨期や秋雨期において、表一 9 で見られた 流出負荷量の南北較差が顕著に現れている。 流域の都市化や下水道の整備が進んでいる南 湖では、北湖に比べて、ポイントソースから の晴天時流出成分が少ない一方で、市街地ノ ンポイント負荷をはじめとするノンポイント ソースからの降雨時流出成分が大きなウエイ 卜を占めている。特に梅雨期や秋雨期には南 湖流出負荷量の $90 \%$ 以上が降雨時流出成分之 なっていることから、今後琵琶湖の富栄養化 防止のためには、南湖へのこうした降雨時流 出負荷量を如何に効率よく制御するかが、重 要な課題であると考えられる。

\section{5.おわりに}

本研究では、琵琶湖流入河川を対象とした マクロモデルによるシミュレーション解析を 行い、琵琶湖への污濁物流出特性を巨視的に 検討する手法を提案した。その結果、集水域 表 -9 降水規模別年間比流出負荷量

\begin{tabular}{|c|c|c|c|c|c|c|}
\hline \multirow{3}{*}{$\begin{array}{l}\text { 区 } \\
\text { 分 }\end{array}$} & \multirow{3}{*}{$\begin{array}{l}\text { 降水量 } \\
(\mathrm{mm} / \mathrm{d})\end{array}$} & \multirow{3}{*}{$\begin{array}{l}\text { 日数 } \\
\text { (d) }\end{array}$} & \multirow{2}{*}{\multicolumn{2}{|c|}{$\frac{T-N}{\text { 比流出負荷量 }}$}} & \multirow{2}{*}{\multicolumn{2}{|c|}{$\frac{T-P}{\text { 比流出負荷量 }}$}} \\
\hline & & & & & & \\
\hline & & & $(\mathrm{kg} / \mathrm{km} 2)$ & \multirow{2}{*}{$\frac{(\mathrm{kg} / \mathrm{km} 2 \cdot \mathrm{d})}{2.9}$} & $(\mathrm{~kg} / \mathrm{km} 2)$ & \multirow{2}{*}{$\frac{(\mathrm{kg} / \mathrm{km} 2 \cdot \mathrm{d})}{0.11}$} \\
\hline & $0 \sim 0.5$ & 242 & $713 \quad(21.2)$ & & $27(11.1)$ & \\
\hline 北 & $0.5 \sim 10$ & 75 & $323 \quad(9.6)$ & 4.3 & $15 \quad(6.2)$ & 0.20 \\
\hline 湖 & $10 \sim 30$ & 33 & $596 \quad(17.7)$ & 18.0 & $41(16.7)$ & 1.25 \\
\hline 東 & $30 \sim 100$ & 14 & $1182(35.1)$ & 86.3 & $105(42.4)$ & 7.66 \\
\hline \multirow[t]{2}{*}{ 岸 } & $100 \sim$ & 1 & $552(16.4)$ & 551.7 & $58 \quad(23.6)$ & 58.42 \\
\hline & 合計 & 365 & $3366(100.0)$ & 9.2 & $246(100.0)$ & 0.68 \\
\hline \multirow{6}{*}{$\begin{array}{l}\text { 北 } \\
\text { 湖 } \\
\text { 西 } \\
\text { 岸 }\end{array}$} & $0 \sim 0.5$ & 242 & $905 \quad(21.7)$ & 3.7 & $23(10.1)$ & 0.10 \\
\hline & $0.5 \sim 10$ & 75 & $399 \quad(9.6)$ & 5.3 & $14 \quad(5.9)$ & 0.18 \\
\hline & $10 \sim 30$ & 33 & $712 \quad(17.1)$ & 21.5 & $39(16.7)$ & 1.17 \\
\hline & $30 \sim 100$ & 14 & $1456 \quad(35.0)$ & 106.3 & $99(42.7)$ & 7.21 \\
\hline & $100 \sim$ & 1 & $694 \quad(16.7)$ & 693.8 & $57(24.5)$ & 56.69 \\
\hline & 合計 & 365 & $4166(100.0)$ & 11.4 & $232(100.0)$ & 0.63 \\
\hline \multirow{6}{*}{$\begin{array}{l}\text { 南 } \\
\text { 湖 } \\
\text { 東 } \\
\text { 岸 }\end{array}$} & $0 \sim 0.5$ & 242 & $711 \quad(13.5)$ & 2.9 & $62 \quad(5.3)$ & 0.26 \\
\hline & $0.5 \sim 10$ & 75 & $439 \quad(8.3)$ & 5.8 & $46 \quad(3.9)$ & 0.62 \\
\hline & $10 \sim 30$ & 33 & $1077 \quad(20.5)$ & 32.5 & $174(14.8)$ & 5.25 \\
\hline & $30 \sim 100$ & 14 & $2118(40.2)$ & 154.6 & $531(45.3)$ & 38.79 \\
\hline & $100 \sim$ & 1 & $921 \quad(17.5)$ & 921.2 & $359 \quad(30.6)$ & 359.20 \\
\hline & 合計 & 365 & $5266(100.0)$ & 14.4 & $1172(100.0)$ & 3.21 \\
\hline \multirow{6}{*}{$\begin{array}{l}\text { 南 } \\
\text { 湖 } \\
\text { 西 } \\
\text { 岸 }\end{array}$} & $0 \sim 0.5$ & 242 & $1323(31.3)$ & 5.5 & $47 \quad(4.8)$ & 0.19 \\
\hline & $0.5 \sim 10$ & 75 & $529(12.5)$ & 7.0 & $44 \quad(4.6)$ & 0.59 \\
\hline & $10 \sim 30$ & 33 & $702 \quad(16.6)$ & 21.2 & $148(15.2)$ & 4.46 \\
\hline & $30 \sim 100$ & 14 & $1179 \quad(27.9)$ & 86.0 & $428 \quad(44.0)$ & 31.22 \\
\hline & $100 \sim$ & 1 & $493(11.7)$ & 493.2 & $305 \quad(31.4)$ & 304.60 \\
\hline & \begin{tabular}{|l|} 
合計 \\
\end{tabular} & 365 & $4226(100.0)$ & 11.6 & $972(100.0)$ & 2.66 \\
\hline \multirow{4}{*}{ 全 } & $0 \sim 0.5$ & 242 & $771 \quad(21.2)$ & 3.2 & $29 \quad(9.6)$ & 0.12 \\
\hline & $0.5 \sim 10$ & 75 & $342 \quad(9.4)$ & 4.5 & $17 \quad(5.5)$ & 0.22 \\
\hline & $10 \sim 30$ & 33 & $644 \quad(17.7)$ & 19.5 & $49(16.2)$ & 1.49 \\
\hline & $30 \sim 100$ & 14 & $1286 \quad(35.3)$ & 93.9 & $131 \quad(43.1)$ & 9.58 \\
\hline \multirow[t]{2}{*}{ 域 } & $100 \sim$ & 1 & $599(16.4)$ & 598.9 & $78 \quad(25.6)$ & 77.91 \\
\hline & 合計 & 365 & $3642(100.0)$ & 10.0 & $304(100.0)$ & 0.83 \\
\hline
\end{tabular}

（）内：区分每の合計に占める各比流出負荷量の割合 $(\%)$ からの晴天時 - 降雨時別の流出負荷量 - 流出 
比負荷量の算定、および流域特性や降水規模, 流出源と流出量の関係を検討する枠組みが示された。しかし、 個別の流域についての精緻な議論を行うには至らないため、今後は、さらに詳細な検討が行えるようモデル の構造を改良するとともに、シミュレーション解析を進め、琵琶湖集水域における合理的な流域管理施策を 検討していきたいと考えている。
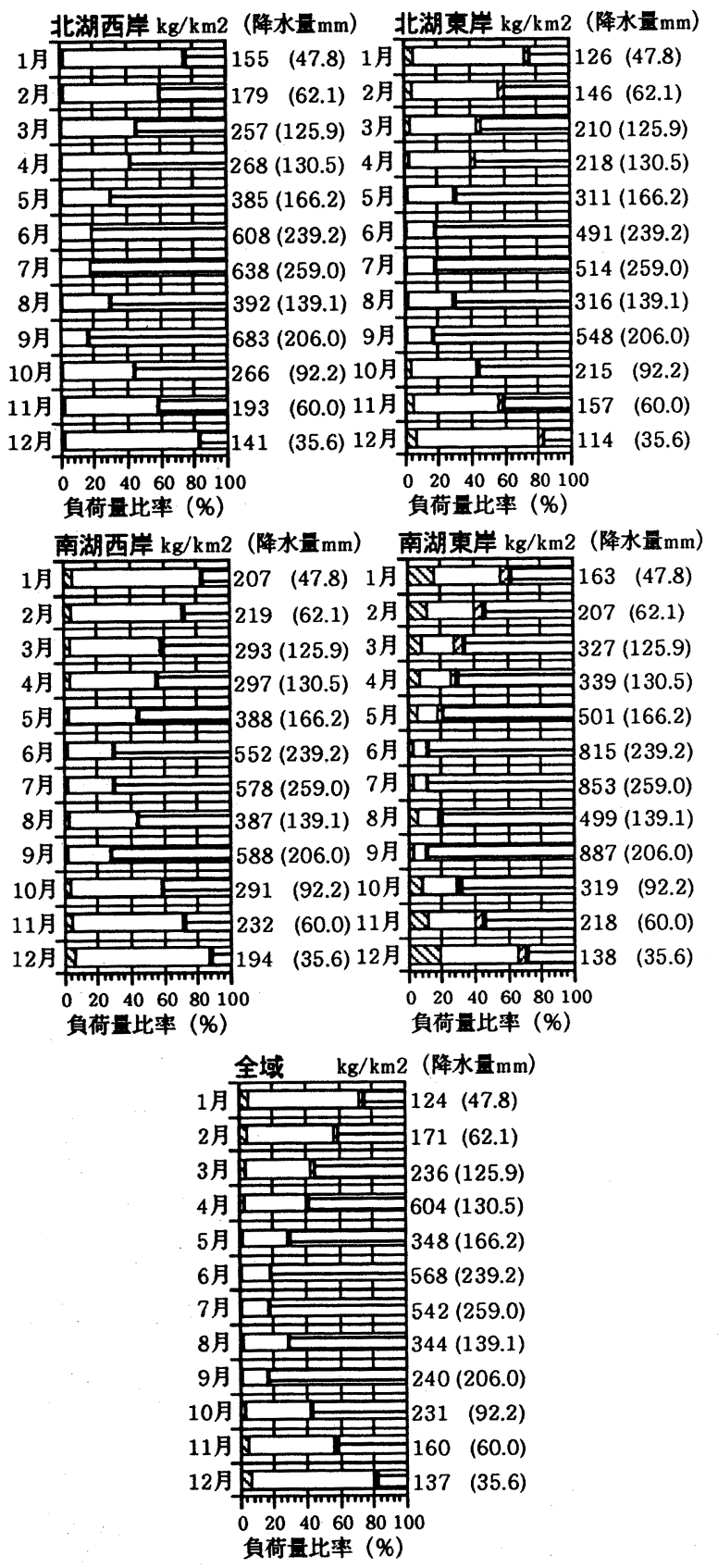

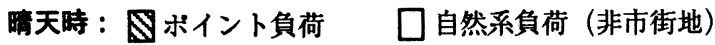
降雨時：【ボイント由来負荷 ロノンボイント負荷（市街地） 目ノンポイント負荷 (非市街地)

北湖西岸 $\mathrm{kg} / \mathrm{km} 2$ (降水量 $\mathrm{mm}$ ) 北湖東岸 $\mathrm{kg} / \mathrm{km} 2($ 降水量 $\mathrm{mm}$ )

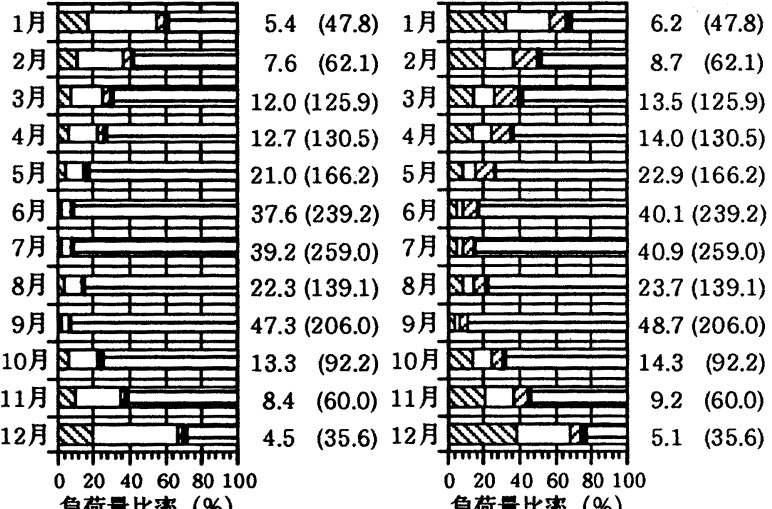

負荷量比率 (\%)

南湖西岸 $\mathrm{kg} / \mathrm{km} 2$ (降水量 $\mathrm{mm}$ ) 南湖東岸 $\mathrm{kg} / \mathrm{km} 2$ (降水量 $\mathrm{mm}$ ) 1月 $16.7(47.8)$ 1月 18.9 (47.8) 2月目 26.5 (62.1) 2 月标 31.1 (62.1) 3月 42.8 (125.9) 3月 51.6 (125.9) 4月 45.8 (130.5) 4月 56.1 (130.5)

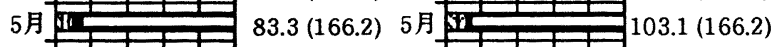
6月 162.2 (239.2) 6月 200.1 (239.2) 7月 167.2 (259.0) 7月 8月 93.9 (139.1) 8月 9月 236.1 (206.0) 9月 $\begin{array}{ll}10 \text { 月 } & \\ 53.4 & (92.2) 10 \text { 月 }\end{array}$ 11月 $30.4(60.0)$ 11月 12月 020406080100 負荷量比率 (\%)

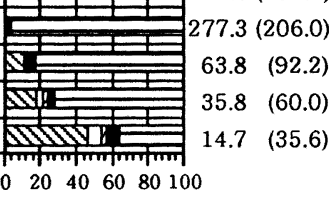

負荷量比率 (\%)

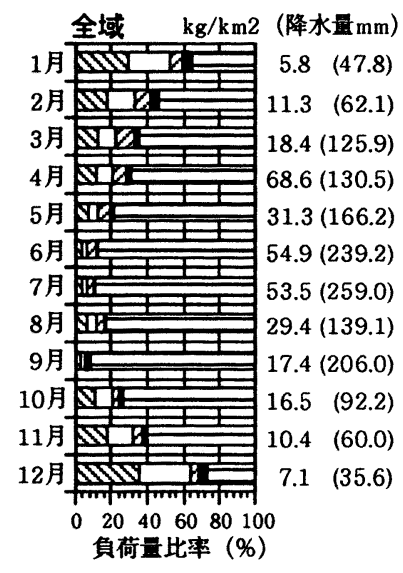
睛天時：\$ボイント負荷口自然系負荷（非市街地）
降雨時：【ポイント由来負荷 ロノンボイント負荷（市街地 目ノンボイント負荷 (非市街地)

図－4（1） 月別比流出負荷量とその流出源比率（T-N） 図-4（2） 月別比流出負荷量とその流出源比率（T- $\mathrm{P}$ 
なお、本研究は、平成 $3 \sim 5$ 年度滋賀県琵琶湖研究所委託研究「都市域の非特定污濁負荷削隇に関する研 究」（研究代表者：山田淳）、および文部省科学研究費補助金・奨励研究 (A)（課題番号 : 07750645, 研究 代表者：市木敦之）による成果の一部である。また、本論文をまとめるにあたり、滋賀県琵琶湖研究所の中 村正久所長にご指導を賜ったことを記し謝意を表する。

$<$ 参考文献 $>$

1) たとえば國松孝男, 須戸幹 (1996) 林地からの水質污濁物質流出の評価について, 第30回日本水環境学会 年会講演集, pp. 508

2) たとえば市木敦之，山田淳 (1993) 粒度特性を考虑した非特定污濁物の流出管理に関する研究一雨水滞水 池を例としてー，環境システム研究，Vol. 21，pp. 436-444

3) 國松孝男 (1986) 河川による物質輸送, 琵琶湖集水域の現状と湖水への物質移動に関する総合研究, 1982 1984年度, 琵琶湖研究所プロジェクト研究記録集, No. $85, \mathrm{~A} 2$

4) 國松孝男, 村岡浩爾編 (1989) 河川污濁のモデル解析, 技法堂出版

5) 原稔明, 西嶋孝治, 加藤正典 (1995) 琵琶湖の水環境モニタリングと湖水位変動, 環境システム研究, Vol. 23, pp. 632-637

6) 市木敦之, 大西敏之, 山田淳 (1996) 集水域における下水道整備進渉にともなう琵琶湖流入污濁負荷量の 変化，水環境学会誌，Vol. 19， No. 2, pp. 109-120

7) 杉本博之, 鈴木研司, 小山勝久 (1995) 琵琶湖・淀川水質浄化共同実験センターについて, 環境システム 研究, Vol. 23, pp. 605-609

8) 滋賀県琵琶湖研究所 (1986) 滋賀県地域環境アトラス

9) 市木敦之, 山田淳, 大西敏之(1994) 流域特性を考虑した污濁物流出プロファイルの予測, 環境システム 研究, Vol. 22, pp. 68-77

10) 市木敦之, 大西敏之, 山田淳 (1995) 水環境における市街地ノンポイントソースの定量評価一栄養塩に 関するシミュレーション解析一, 環境システム研究, Vol. 23, pp. 12-19

11) 市木敦之, 山田淳, 辰巳直, 阿部野剛 (1996) 都市域中小河川における降雨時污濁物流出モニタリング 調查, 土木学会関西支部年次学術講演会講演概要集, pp. II -146-1- II -146-2 